\title{
Pengaruh Kemiskinan Keluarga pada Kejadian Pneumonia Balita di Indonesia
}

\author{
Rizanda Machmud*
}

\begin{abstract}
Abstrak
Pneumonia merupakan penyakit infeksi saluran pernapasan akut yang menjadi kausa utama kematian balita. Di Indonesia, pada akhir tahun 2000, angka kematian balita akibat pneumonia diperkirakan 4,9/1000 balita. Faktor sosio-ekonomi berkontribusi besar terhadap penyakit saluran pernapasan. Tujuan penelitian ini adalah mengetahui faktor sosio-ekonomi yang paling berpengaruh terhadap pneumonia pada balita. Penelitian dengan dengan disain krosseksional ini menggunakan sumber data sekunder Benefit Evaluation Study (BES) II oleh Pusat Penelitian Kesehatan Universitas Indonesia bekerja sama dengan Proyek Intensifikasi Pemberantasan Penyakit Menular, Departemen Kesehatan. Sampel diambil berdasarkan multilevel statistical framework dari 7.170 balita pada 10.900 rumah tangga di 27 kabupaten di tujuh provinsi. Metode analisis yang digunakan adalah multilevel logistic regression. Penelitian ini memperlihatkan bahwa sosio-ekonomi rumah tangga berperan secara bermakna terhadap kejadian pneumonia balita. Rumah tangga miskin berisiko lebih besar untuk terkena pneumonia. Pada keluarga miskin, risiko pneumonia yang lebih besar disebabkan oleh faktor kontekstual lingkungan yang buruk berupa pencemaran di dalam rumah yang dikontrol faktor komposisi status gizi (95\% Cl OR 4.05- 4.78). Kebijakan intervensi program P2ISPA disarankan lebih mengutamakan intervensi pada faktor kontekstual lingkungan buruk pencemaran dalam rumah tangga miskin.
\end{abstract}

Kata kunci : Pneumonia, sosio-ekonomi, balita

\section{Abstract}

Pneumonia is an acute respiratory tract infection disease that becomes a major cause of death among under five years old children. In Indonesia, in 2000 , pneumonia specific cause of death rate among under five children is predicted to be $4.9 / 1000$. The socio-economic factor has significant contribution to respiratory tract infection. The objective of this study is to know the socioeconomic factor that affect pneumonia among under five children. The study uses cross sectional study design using secondary data of Benefit Evaluation Study (BES) II conducted by Centre for Health Research, University of Indonesia in collaboration with Intensification of Infectious Diseases Eradication Project, MOH-RI. The study sample is selected based on multilevel statistical framework from 7170 under five children in 10900 households within 27 districts in seven provinces. Analysis method used in this study is multilevel logistic regression. This study shows that the low level of socioeconomic status affect significantly the pneumonia occurrence among under five children. The risk of pneumonia among lower socioeconomic household is higher than that of the high socioeconomic household. It was found that the association was found for poor environmental factor including in-house hygienic condition after controlled by nutritional status. The pneumonia occurrence among under five children is more influenced by environmental factors than individual factors (compositional effect). It is suggested to prioritize intervention on environmental factors to eradicate respiratory tract infection.

Key words : Pneumonia, socio-economic, under five years old children

*Bagian IImu Kesehatan Masyarakat dan IImu Kedokteran Komunitas FK Universitas Andalas, Jl. Perintis Kemerdekaan, Padang (e-mail: rizanda_machmud@yahoo.com) 
Di Indonesia, insiden pneumonia memperlihatkan kecenderungan yang meningkat tajam dari tahun 1990 (5 per 10.000 penduduk) menjadi tahun 1998 (212.6 per 10.000 penduduk). Hasil Survei Kesehatan Nasional (Surkesnas) tahun 2001, menunjukkan bahwa proporsi kematian bayi akibat ISPA masih terlalu tinggi (28\%) dan $80 \%$ disebabkan oleh pneumonia. Angka Kematian Balita akibat pneumonia pada akhir tahun 2000 di Indonesia diperkirakan sekitar 4,9 per 1000 balita, berarti rata-rata 1 anak balita Indonesia meninggal akibat pneumonia setiap 5 menit. ${ }^{1}$

Pemerintah Indonesia bersama masyarakat dunia telah mengambil langkah untuk menurunkan angka kematian akibat pneumonia. Hal ini terbukti dengan diberlakukannya Keputusan Presiden Nomor 36 Tahun 1990 tentang Konvensi Hak-Hak Anak dan Undang-Undang Nomor 25 Tahun 2000 tentang Program Pembangunan Nasional (Propenas) 2000-2004. Sasaran upaya tersebut antara lain adalah menurunkan angka kematian akibat pneumonia balita menjadi 3 per 1000 dan menurunkan angka kesakitan balita akibat pneumonia dari $10-20 \%$ pada tahun 2000 menjadi $8-16 \%$ pada tahun 2004. ${ }^{1}$

Faktor sosio-ekonomi berkontribusi besar terhadap penyakit saluran pernapasan akibat hubungan terbalik antara status sosial ekonomi dan morbiditas infeksi saluran pernafasan akut. ${ }^{2}$ Di negara berkembang terlihat hubungan yang jelas antara status sosial ekonomi yang diukur dari besar rumah tangga, banyak kamar, dan banyak orang yang menghuni tiap kamar dengan kejadian pneumonia balita. ${ }^{3}$

Penelitian peranan sosio-ekonomi terhadap penggunaan pelayanan dokter yang dilakukan di Nova Scotia Amerika, menunjukkan bahwa sosio-ekonomi rendah lebih banyak mengunjungi pelayanan dokter daripada sosio-ekonomi yang lebih tinggi. Penduduk dengan pendapatan yang lebih rendah berisiko $43 \%$ (OR 1,43; 1,12-1,84) daripada sosio-ekonomi yang lebih tinggi. Penduduk berpendidikan lebih rendah lebih banyak mengunjungi pelayanan kesehatan $49 \%$, daripada yang berpendidikan lebih tinggi (OR 1,49; 1,24-1,79). 6

Penelitian di Amerika Serikat, terhadap kematian pneumonia balita yang diamati sejak tahun 1939 sampai 1996 menunjukkan bahwa selama 58 tahun periode penelitian, terjadi penurunan jumlah anak yang meninggal sebesar $98 \%$. Salah satu program yang dilakukan untuk menurunkan kematian pneumonia balita pada tahun 1972 adalah meningkatkan akses penduduk miskin ke fasilitas pelayanan kesehatan dalam program The Women, Infants and Children. ${ }^{7}$

Peranan perbedaan sosio-ekonomi pada kesehatan anak yang berubah menurut waktu. Memperlihatkan hubungan pola monotonic pada anak-anak dan dewasa. Pada status sosio-ekonomi yang menurun, semua penyebab kematian dan seluruh angka kesakitan akan meningkat. Monotonic effect tersebut menunjukkan bahwa hubungan yang terjadi tidak semata-mata disebabkan oleh masalah kemiskinan yang berperan besar pada anak. Hasil evaluasi juga menunjukkan bahwa risiko cedera, asma, dan hipertensi pada remaja meningkat akibat perilaku negatif pada anak-anak dari sosio-ekonomi rendah. Namun, risiko cedera dan peningkatan tekanan darah pada dewasa muda tidak terdapat lagi. Keadaan ini dihubungkan dengan unhiggenic environment yang terdapat pada sosio-ekonomi rendah seperti: konflik, child care quality, stress hidup, akses pelayanan kesehatan yang minim. ${ }^{8}$

\section{Metode}

Penelitian menggunakan metode survei rumah tangga yang mengukur berbagai faktor pada level rumah tangga dan level individu serta survei institusi yang mengukur faktor kinerja program pada level kabupaten. Penelitian dengan sumber data sekunder Benefit Evaluation Study (BES) II oleh Pusat Penelitian Kesehatan Universitas Indonesia bekerja sama dengan Proyek Intensifikasi Pemberantasan Penyakit Menular (IPPM), Direktorat Jenderal Pemberantasan Penyakit Menular dan Penyehatan Lingkungan Pemukiman (Ditjen P2MPL), Departemen Kesehatan.

Lokasi penelitian adalah 27 kabupaten yang meliputi tujuh provinsi di Indonesia. Di Sumatera Selatan meliputi Ogan Komering Ulu, Muara Enim, dan Musi Rawas; di Bangka Belitung (Kabupaten Bangka), di Jawa Barat meliputi Tasikmalaya, Sukabumi, Majalengka, Bandung, dan Ciamis; di Jawa Tengah meliputi Indramayu, Wonosobo, Jepara, Kebumen, Banjarnegara; di Kalimantan Selatan meliputi Banjarmasin, Tanah Laut, Hulu Sungai Tengah, Kotabaru Tapin; di Sulawesi Tengah meliputi Banggai, Toli-toli, Donggala. Di Nusa Tenggara Timur meliputi Sumba Barat, Flores Timur, Sumba Timur, Timor Timur Selatan.

Populasi target adalah seluruh anak balita yang tinggal di area penelitian. Besar sampel dihitung menggunakan rumus perhitungan sampel untuk penelitian. Perkiraan ukuran sampel dan survei BES II, berdasarkan pada metodologi Multistage Cluster dengan probabilitas proportionate to the size (PPS) dari populasi tiap cluster, 95\% confidence interval diterapkan. Penghitungan ukuran sampel berdasarkan pada estimasi tingkat prevalensi pneumonia pada anak di bawah lima tahun. Batas ketepatan harus diputuskan berdasarkan estimasi tingkat prevalensi. Estimasi prevalensi pneumonia pada anak-anak di bawah 5 tahun di dalam provinsi IPPM (ICDC) 2001 berkisar antara 4,0\% sampai $6,2 \%$, confidence interval, $+0,01 \%$ batas presisi 


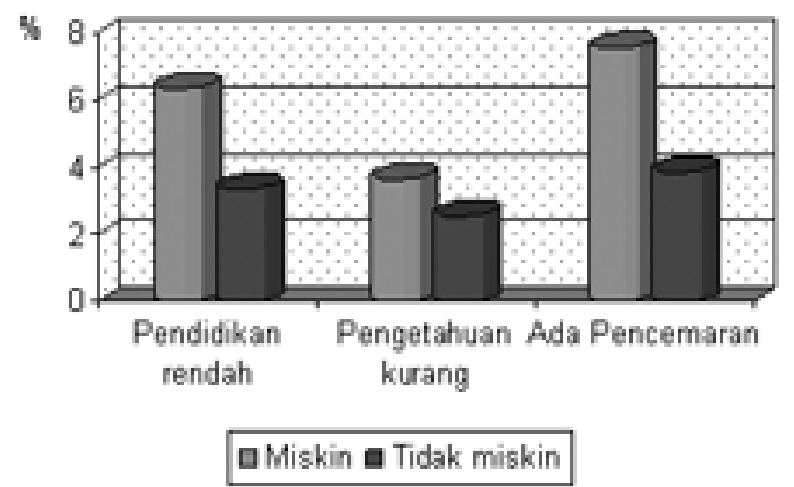

Gambar 1. Distribusi Pneumonia berdasar Status Miskin, Pendidikan, Pengetahuan, dan Pencemaran dalam Rumah

Tabel 1. Modelling Multilevel Kejadian Pneumonia Variabel Level Balita, Rumah Tangga dan Kabupaten di Tujuh Provinsi di Indonesia, Tahun 2004

\begin{tabular}{lllll}
\hline Fixed Effect & Coef $\mathbf{B}$ & Or & $\mathbf{9 5 \%} \mathbf{C i}$ & Nilai $P$ \\
\hline Constanta $)$ & -2.588 & & & 0.000 \\
Level Balita & & & & \\
Gizi buruk & -0.160 & 0.85 & $0.49-1.49$ & 0.574 \\
Gizi kurang & -0.446 & 0.64 & $0.32-1.29$ & 0.211 \\
Gizi Baik & 0.081 & 1.08 & $0.81-1.45$ & 0.587 \\
Umur & 0.002 & 1.00 & $0.93-2.11$ & 0.947 \\
Jenis kelamin & -0.141 & 0.87 & $0.68-1.10$ & 0.249 \\
& & & & \\
Level Rumah Tangga & & & & \\
Pendidikan ibu & 0.167 & 1.18 & $0.91-1.54$ & 0.216 \\
Pengetahuan ibu & -0.941 & 0.39 & $0.30-0.51$ & $0.000^{*}$ \\
Sosio ekonomi & 0.551 & 1.73 & $1.34-2.25$ & $0.000^{*}$ \\
Level Kabupaten & & & & \\
Kategori kinerja program & -0.583 & 0.56 & $0.31-0.36$ & $0.007^{*}$ \\
Fasilitas kesehatan & -0.187 & 0.83 & $0.68-1.02$ & 0.073 \\
IPM rendah & 0.581 & 1.79 & $0.72-4.45$ & 0.212 \\
IPM menengah & 0.600 & 1.82 & $1.79-3.13$ & $0.030^{*}$ \\
Sumatera & 0.995 & 2.70 & $1.45-3.20$ & $0.002^{*}$ \\
Kawasan timur Indonesia & 0.765 & 2.15 & $0.92-5.02$ & 0.077 \\
& & & & \\
Random Effect & Varians & SE & & 1.00 \\
Level 2 (rumah tangga) & $1.22 \mathrm{e}-09$ & 0.000013 & & 0.00 \\
Level 3 (kabupaten) & 0.150 & 0.074 & & \\
\hline Ketan : P<0.005 & & & & \\
\hline
\end{tabular}

Keterangan : * $\mathrm{P}<0.005$

diterapkan dan dikalikan dengan efek disain 2, sehingga hasil sampel minimum 2,952 balita. Besar sampel yang didapatkan pada BES II sebagai sampel penelitian ini melebihi sampel minimal yaitu 7170 balita pada 10.900 rumah tangga di 27 kabupaten pada 7 provinsi pada tahun 2004-2005, seluruhnya diambil sebagai sampel. Ukuran populasi ini secara acak dialokasikan ke dalam 30 clusters di tiap provinsi, dan The Primary Sampling Units (PSUs) atau clusters adalah desa-desa.

Variabel yang diukur berupa faktor risiko individu (faktor anak meliputi status gizi, umur, jenis kelamin), faktor risiko kontekstual yang meliputi faktor risiko rumah tangga (faktor ibu meliputi pendidikan, pengetahuan, faktor lingkungan, faktor sosio-ekonomi) dan faktor risiko tingkat kabupaten (indeks kinerja program, fasilitas kesehatan kabupaten, SDM kesehatan kabupaten, faktor geografis, indeks pembangunan manusia) terhadap kejadian pneumonia. Variabel ini dituangkan dalam kuesioner pada tingkat anak dan ibu. Data level kabupaten yang tidak didapatkan dari data BES II, diambilkan 
Tabel 2. Modelling Multilevel Variabel Sosio-ekonomi Rumah Tangga Terhadap Faktor Gizi, Pendidikan Ibu, Pengetahuan Ibu dan Pencemaran dalam Rumah

\begin{tabular}{|c|c|c|c|c|c|c|}
\hline \multirow[t]{2}{*}{ Fixed Effect } & \multicolumn{6}{|c|}{ Faktor Outcome Nilai OR dan ( $95 \%$ CI OR) } \\
\hline & Gizi Buruk & Gizi Kurang & Gizi Gemuk & Pendidikan & Pengetahuan & Pencemaran \\
\hline \multicolumn{7}{|l|}{ (Constanta) } \\
\hline \multicolumn{7}{|l|}{ Level Balita } \\
\hline \multirow{2}{*}{\multicolumn{7}{|c|}{$\begin{array}{l}\text { Umur } \\
\text { Jenis Kelamin }\end{array}$}} \\
\hline & & & & & & \\
\hline \multicolumn{7}{|l|}{ Level RT } \\
\hline \multirow[t]{2}{*}{ Sosio Ekonomi } & 1.08 & 1.14 & 1.15 & 2.90 & 1.27 & 3.23 \\
\hline & $\left(0.85 \_1.38\right)$ & $\left(0.89 \_1.46\right)$ & $\left(1.18 \_1.32\right)$ & $\left(2.54 \_3.29\right)$ & $\left(1.13 \_1.42\right)$ & $\left(2.83 \_3.70\right)$ \\
\hline \multicolumn{7}{|l|}{ Level Kabupaten } \\
\hline Random Effect & Varians & Varians & Varians & Varians & Varians & Varians \\
\hline Level 2 (RT) & 0.131 & 0.024 & 8.9 E-06 & 0.049 & 0.086 & 0.033 \\
\hline Level 3 (Kabupaten) & 0.374 & 0.149 & 0.588 & 0.157 & 0.803 & 0.537 \\
\hline
\end{tabular}

dari pengolahan data Biro Pusat Statistik data tahun 2004 antara lain: penggunaan data indeks pembangunan manusia (IPM), data dan informasi kemiskinan kabupaten, fasilitas kesehatan dan sumber daya kesehatan per kabupaten serta Laporan Kemiskinan Masyarakat yang diterbitkan bersama oleh BPS, Bappenas, UNDP. BPS dan Kabupaten. Untuk kualitas data dilakukan uji coba kuesioner, supervisi yang ketat di lapangan, cros check data dan double entry. Metode analisis menggunakan multilevel logistic regression menggunakan program STATA.

\section{Hasil}

Perbedaan besar proporsi kejadian pneumonia balita pada kelompok miskin dengan pengkategorian pendidikan, pengetahuan dan pencemaran terlihat pada Gambar 1. Terlihat proporsi yang jauh lebih besar bagi keluarga yang memiliki sosio-ekonomi miskin untuk mendapatkan kejadian pneumonia balita pada keadaan yang samasama berpendidikan rendah, berpengetahuan kurang dan sama-sama ada pencemaran.

Analisis multilevel juga memberikan besar hubungan antara pneumonia balita dan variabel yang berperan, baik pada level rumah tangga maupun kabupaten dalam bentuk nilai odds ratio(OR). Arti nilai odds ratio adalah besarnya hubungan antara dua faktor yang menunjukkan besarnya risiko suatu faktor terhadap kejadian penyakit. Nilai OR yang didapat disebut sebagai nilai OR adjusted karena nilai tersebut telah dikontrol oleh variabel-variabel yang ada dalam model regresi multilevel tersebut sehingga besarnya risiko suatu faktor terhadap kejadian penyakit yang telah dikontrol oleh faktor lainnya (Lihat Tabel 1).

Pada level rumah tangga, faktor risiko adalah sosioekonomi rumah tangga miskin. Balita berisiko mendapatkan pneumonia sebesar 1,73 kali (CI 95\%; OR
$1,34 ; 2,25)$ dalam lingkungan rumah tangga yang dikategorikan miskin dibandingkan rumah tangga yang tidak miskin. Besar kontribusi faktor kemiskinan sebesar 19,9\% dalam kejadian pneumonia balita. Bila diasumsikan kemiskinan dapat diatasi dalam keluarga, maka prevelensi pneumonia balita akan menurun dari 5,4\% menjadi 4,33\% (interval kepercayaan 95\% 4,05; 4,78).

Penelitian ini memperlihatkan bahwa sosio-ekonomi rumah tangga berperan secara bermakna terhadap kejadian pneumonia balita, yang berarti rumah tangga miskin akan lebih besar terkena pneumonia.

Risiko rumah tangga yang dikategorikan miskin, berisiko mendapatkan pneumonia balita yaitu sebesar 1,73 kali dibandingkan dengan orang yang tidak miskin. Sementara itu, besar kontribusi kemiskinan terhadap kejadian pneumonia balita yaitu sebesar 19,9\%. Artinya, besarnya proporsi kasus pneumonia balita di 7 provinsi di Indonesia terjadi akibat kemiskinan. Bila diasumsikan seluruh anak balita berada pada rumah tangga yang tidak miskin, prevelensi pneumonia balita akan menurun dari 5,4\% menjadi 4,33\% (95\% CI OR 4,05; 4,78).

Pemodelan multilevel selanjutnya adalah untuk melihat faktor yang sangat berpengaruh terhadap peranan sosio-ekonomi terhadap pneumonia balita yang melibatkan: 1 . anak sebagai faktor compositional (status gizi) dan 2. ibu (pendidikan dan pengetahuan) dan pencemaran lingkungan (pencemaran dalam rumah) sebagai faktor kontekstual. Hasil pemodelan ditemukan nilai faktor pencemaran udara dalam rumah memiliki nilai OR paling tinggi dibandingkan faktor-faktor lain (Lihat Tabel 2).

Hal ini dapat diterjemahankan bahwa timbulnya pneumonia pada keluarga dengan sosio-ekonomi miskin, karena peran lingkungan yang buruk, yaitu adanya pencemaran dalam rumah, lebih besar dari peran status gi- 
zinya. Hal ini sejalan dengan pemodelan yang dilakukan oleh Mosley and Chen tentang Kelangsungan Hidup Anak/Child Survival. ${ }^{4}$ Dengan kata lain, faktor kontekstual lebih berperan dibandingkan faktor compositional. Sehingga, intervensi terhadap keluarga miskin hendaknya lebih mengutamakan intervensi di faktor kontekstual dibandingkan faktor compositional.

\section{Pembahasan}

Hasil penelitian yang didapatkan mendukung datadata penelitian lainnya, bahwa kemiskinan merupakan masalah global di seluruh dunia. Salah satu program yang dilakukan untuk menurunkan kematian karena pneumonia balita pada tahun 1972 adalah dengan meningkatkan akses penduduk miskin ke fasilitas pelayanan kesehatan dalam program The Women, Infants and Children. ${ }^{7}$ Program ini menunjukkan dampak kematian karena pneumonia balita yang diamati sejak tahun 1939 sampai 1996 menunjukkan bahwa selama 58 tahun periode penelitian, terjadi penurunan jumlah anak yang meninggal sebesar $98 \% .8,9$

Terminologi kemiskinan diterjemahkan secara luas dan multidimensional setelah diterbitkannya World Development Report 2000/2001. Hal tersebut bermakna derajat kesehatan dan ill-health merupakan dimensi yang sangat penting dan esensial. Pergeseran dimensi ini membawa implikasi karena dalam dimensi baru dikatakan bahwa peningkatan pendapatan tidak menjamin secara otomatis terjadinya penurunan kemiskinan kecuali derajat kesehatan kelompok miskin juga ditingkatkan. Dalam kondisi shifting dimensi, pembiayaan pelayanan kesehatan juga harus mendapat perhatian sehingga terjadi peningkatan derajat kesehatan. ${ }^{5,10}$ Hal ini akan berdampak pada peningkatan pendapatan penduduknya. Perwujudan menuju peningkatan derajat kesehatan suatu hal yang tidak mudah karena diperlukan pemahaman dan kemauan politis yang kuat seperti pernyataan 'by securing greater proportional improvements amongs poorer groups, is not simply poverty issues - it is also a question of justice and equity.'11,12

Salah satu wujud pergeseran ini dilihat dari pergeseran besaran persentase alokasi anggaran untuk kesehatan di suatu daerah, alokasi anggaran pemerintah seharusnya bergeser untuk lebih ke arah pembiayaan pada masalah-masalah kesehatan kelompok rentan dan miskin. ${ }^{13,14}$ Upaya ini dapat dilihat bagaimana keseimbangan anggaran pemerintah dialokasikan dan digunakan di setiap wilayah kerja daerah untuk peningkatan derajat kesehatan. Besaran anggaran pemerintah tersebut diwujudkan untuk masalah kesehatan yang bersifat 'public good' dan kesehatan perorangan keluarga rentan dan miskin di semua wilayah, mendapat proporsi seimbang sesuai dengan kondisi daerahnya masing- masing. 15

\section{Kesimpulan}

Analisis pemodelan multilevel terhadap pneumonia menunjukan sosio-ekonomi merupakan faktor yang turut berkontribusi. Hasil analisis multilevel lebih lanjut pada keluarga miskin menunjukkan bahwa pneumonia berisiko lebih besar karena peran faktor kontekstual lingkungan yang buruk pencemaran dalam rumah daripada faktor compositional status gizi. Hal tersebut menunjukkan kemiskinan terstuktur merupakan pangkal ketidakmampuan seorang untuk berpendidikan lebih tinggi, mendapatkan lingkungan rumah lebih baik, akses pengetahuan lebih baik. Berbagai faktor tersebut justru semakin meningkatkan risiko penyakit. Biaya pengobatan yang mahal menyebabkan keluarga tersebut menjadi lebih miskin. Kemiskinan merupakan pangkal penyebab risiko pneumonia balita pada level rumah tangga yang lebih besar. Balita bergizi baik dan buruk jika berada dalam rumah tangga miskin berisiko lebih besar untuk menderita pneumonia. Proporsi tersebut akan bertambah besar pada balita dengan pendidikan ibu rendah, pengetahuan pneumonia rendah, dan kondisi lingkungan buruk. Faktor tersebut merupakan dampak kemiskinan. Faktor kontekstual lebih berperan daripada faktor anak.

\section{Saran}

Intervensi pneumonia pada balita keluarga miskin hendaknya lebih mengutamakan intervensi pada faktor kontekstual, faktor lingkungan yang buruk pencemaran dalam rumah tangga miskin yang berisiko lebih besar untuk menderita pneumonia dari pada faktor anak.

\section{Daftar Pustaka}

1. Departeman Kesehatan Republik Indonesia. Pedoman pemberantasan penyakit infeksi saluran pernapasan akut untuk penanggulangan pneumonia pada balita. Jakarta: Departeman Kesehatan RI; 2004.

2. Purwana R. Partikulat rumah sebagai faktor risiko gangguan pernapasan anak balita (penelitian didaerah Pekojan, Jakarta) [disertasi]. Depok: Fakultas Kesehatan Masyarakat, Universitas Indonesia; 1999.

3. Foster SO. Immunizable and respiratory diseases and child mortality in Mosley Whenry, Lincoln C Chen, Child Survival, strategies for research. Population and development review A supplement to volume 10 . Cambridge university press; 1984.

4. Mosley W, Lincoln CC. Child survival, strategies for research. Population and development review A supplement to volume 10 . Cambridge university press; 1984.

5. BPS, BAPPENAS, UNDP. Indonesia laporan pembangunan manusia. Ekonomi dari Demokrasi. Membiayai Pembangunan Manusia Indonesia. 2004.

6. Kephart G; Vince ST, David RM. Socioeconomic differences in the use 
of physician services in Nova Scotia. American Journal of Public Health. 1998; 88: 5.

7. Dowell SF, Benjamin AK, Elizabeth R Z, Stat M, David K S. Mortality from pneumonia in children in the united states, 1939 through 1996. NEMJ; 342:1399-407.

8. Chen E, Karen AM, Boyce WT. Socioeconomic differences in children's health: how and why do these relationships change with age? Psycchological Bulletin. 2002; 128 (2): 295-329.

9. Niessen LW \& Hilderink HBM. The population and health model. Ch 4 in: Rotmans J and De Vries (eds): Perspectives on global change: the TARGETS approach. Cambridge UP: 1997.

10. Ostapchuck M, Donna MR, Richard H. Community-acquired pneumonia in infants and children. American Family Physician. 2004;
70 (5).

11. Hsiao G, Cindy BP, Campbell GD. Pediatric Community-Acquired Pneumonia. Lesson 11. Thorax. 1998; 53: 549-553,

12. WHO. The management of acute respiratory infections in children, practical guidelines for out patients care. Jenewa: WHO; 1995.

13. Humpreys, Keith; Roy CH. Area variation in health outcomes: artefact or ecology. International Journal of Epidemiology. 1991; 21 (1).

14. Subramian SV, Delgado I, Jadue L, Vega J, Kawachi I. Income inequality and health : multilevel analysis of chilean commuties. Jurnal Epidemiology Community Health. 2003; 57:844-8.

15. Kennedy BP, Ichiro K, Oberta G, Deborah PS. Income distribution, socioeconomic status, and self rated health in The United States : multilevel analysis. BMJ. 1998; 917-21. 